\title{
ANALYSIS OF ANTIOXIDANT CAPACITY AND POLYPHENOL CONTENT OF GOJI FRUIT PRODUCTS AVAILABLE ON THE EUROPEAN MARKET
}

\author{
IZABELA A. BOLESŁAWSKA ${ }^{1}$, GRZEGORZ KOSEWSKI ${ }^{1}$, PAWEŁ JAGIELSKI ${ }^{2}$, \\ MAŁGORZATA DOBRZYŃSKA ${ }^{1}$, and JULIUSZ PRZYSŁAWSKI ${ }^{1}$
}

\author{
${ }^{1}$ Chair and Department of Bromatology, Faculty of Pharmacy, Poznan University of Medical Science, \\ Marcelińska 42, 60-354 Poznań, Poland \\ ${ }^{2}$ Department of Nutrition and Drug Research, Faculty of Health Sciences, Institute of Public Health, \\ Jagiellonian University, Skawińska 8, 31-066 Kraków, Poland
}

\begin{abstract}
The berries of Barbary wolfberry (Lycium barbarum L.) are used in alternative medicine as a nutraceutical. However, it has been shown that specific therapeutic effects are observed only in the very high concentrations of defined active ingredients from strictly selected phytochemical species of Lycium. Therefore, this study was carried out to compare the antioxidant properties and the content of polyphenols and flavonoids in dried berries, juices, and capsules containing goji berry extract. To determine the antioxidative potential of the tested products, methanol extracts of DPPH radical were employed, while to determine the polyphenol content the Folin-Ciocalteu reagent was used. The flavonoid content was determined using Dowd colorimetric method. This study showed that the dried goji berries were characterized by the highest content of polyphenols and flavonoids and having the highest antioxidant activity from all analyzed products. The significantly lower concentrations of studied components were observed in juices and the lowest in capsules. However, on a per-dose basis, the highest concentrations were observed for juice.
\end{abstract}

Keywords: dried goji berries, capsules, juices, antioxidant activity, polyphenols, flavonoids

Goji is a popular name of the Asian Barbary wolfberry plant (Lycium barbarum L.), whose berries have a pro-health effect on the human body. Currently, they have become very popular in Western Europe and are used there as a functional food (1). The Species Lycium barbarum and Lycium chinensis are characterized by a particularly high content of bioactive compounds $(2,3)$.

Despite not fully explained clinical efficacy, various parts of the Goji plant: flowers, leaves, and berries can have beneficial effects in the prevention and treatment of cancer or metabolic and retinal diseases $(2,4,5)$. This is confirmed by the results of many studies indicate that the goji berries components in addition to the impact on carbohydrate and lipid metabolism $(6,7)$ have strong antioxidant properties, among others, the ability to scavenge superoxide anions, radical DPPH, ABTS $^{++}$and hydroxyl radicals $(8,9)$.

They are also characterized by strong antioxidant properties in the process of hemolysis of erythrocytes induced by 2-amidinopropane dihydrochloride (AAPH), they can also act as electron donors and react with free radicals thus breaking radical chain reactions $(2,4,10)$.

However, it has been shown that to induce a therapeutic effect, very high concentrations of specific active ingredients, coming from strictly defined phytochemical species, are needed. Therefore, doubts arise from widely advertised and sold products of unclear origin and composition (2).

From Goji berries currently were isolated many compounds. The best known isolated chemical group is water-soluble glycoconjugates LBP (Lycium barbarum polysaccharides) consisting of a mixture of branched polysaccharides and proteoglycans, galacturonic acid, and amino acids (9-11). In addition, they contain compounds that increase the nutritional value, among others $\beta$-sitosterol and its glycosides, carotenoids, glycol- galacto- lipids and amino acids, as well as minerals and vitamins (iron, calcium, zinc, selenium, copper, manganese, and magnesium) (C, E, $\left.\mathrm{B}_{1}, \mathrm{~B}_{2}, \mathrm{~B}_{6} \mathrm{PP}\right)$ as well as polyphenolic compounds among which the most numerous group are flavonoids $(43 \%)(8,10-12)$. The most important characteristic of flavonoids is their high antioxidant

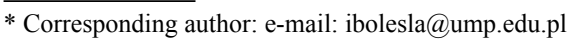


potential, thus demonstrating cardioprotective properties, as well as cancer prevention and anti-inflammatory and immunomodulatory effects $(2,9,13,14)$. However, excessive consumption of these berries can cause serious side effects in some individuals. Studies indicate that they can cause allergies $(15,16)$ and some drug interactions $(16,17)$ especially with anticoagulants (18). It is recommended that patients with diarrhea, fever, severe inflammation, and pregnant women avoid eating these berries (2).

Although the antioxidant properties of Goji fruits are not doubtful, however the products available in stores, both in unprocessed fruits form as well as in juices and capsules are often not tested of the content of bioactive components, and their pharmaceutical properties are characterized by high variability (19). This is due to the fact that the applied technological processes during fruit processing can reduce the content of active compounds, which makes Goji products on sale are often only functional by name. Therefore, the present study attempts to compare the antioxidant properties of Goji berries with capsules containing Goji berry extract and juices from various European producers. Simultaneously, the content of polyphenols including flavonoids was evaluated.

\section{EXPERIMENTAL}

\section{Materials}

The research material included the following products: three different products of dried goji berries (numbers: 1, 2, 3), three different products of juice goji berries (numbers: $4,5,6$ ), and three different capsules containing goji berries extract (numbers: $7,8,9)$. All products were bought in pharmacies, health food stores, or markets in Poland, Germany, and United Kingdom. The research was carried out immediately after the purchase date, products did not exceed the expiration date. It is worth noting that the information on the packaging often did not contain information about the origin country and the composition of this product. Dosage was specified by the producer for capsules only (1 capsule per day in all cases) and for juice - trial no. 5 and 6 at $50 \mathrm{ml} /$ day.

\section{Methods}

\section{Evaluation of antioxidant properties of Goji products \\ Extraction}

The extraction of the test materials was conducted at three stages using $80 \%$ methanol (Sieger, 2010). The first fraction was obtained by shaking $10 \mathrm{~g}$ of studies raw material with $50 \mathrm{~mL}$ of $80 \%$ methanol in a water bath with shaker function (Series SWB $16 \mathrm{~N}$, Labo play company, Poland) for $30 \mathrm{~min}$ at $50^{\circ} \mathrm{C}$. The obtained extract was poured out into a conical flask and $25 \mathrm{~mL}$ of $80 \%$ methanol was added to the remaining part again at the first stage. The third fraction was obtained in the same way as a second and combined with previous extracts. Fractions from all three steps were filtered on a Büchner funnel with a qualitative filter with an average filtration rate. The resulting filtrate was poured into a $100 \mathrm{~mL}$ flask and filled to the line with an $80 \%$ methanol solution. It is worth noting, the dried goji berries had been previously minced using a food processor.

\section{Determination of antioxidative activity using the DPPH radical}

To determine the antioxidant effect of the extracts using the $0.1 \mathrm{mM}$ methanol solution of DPPH radical. To the $2.5 \mathrm{~mL}$ finished reagent, the tested extract was added and incubated in the dark for $30 \mathrm{~min}$, after that an absorbance at $\lambda=517 \mathrm{~nm}$ was measured. The free radical scavenging capacity calculated on the Trolox equivalent was read from the standard curve. The standard curve was prepared using a methanol solution of Trolox at concentrations of $0.02 \mu \mathrm{M}$ to $0.08 \mu \mathrm{M}$ and repeating every single concentration 5 times $(\mathrm{y}=891.49 \mathrm{x}$, $\left.\mathrm{R}^{2}=0.984\right)(20)$.

\section{Determination of total polyphenol content}

The total polyphenol content was determined by the Folin-Ciocalteu colorimetric method. To a $1 \mathrm{~mL}$ of the extract, $1 \mathrm{~mL}$ of Folin-Ciocalteu reagent, and after $5 \mathrm{~min}$ of waiting, $1 \mathrm{~mL}$ of sodium carbonate solution were added. Next distilled water was added to obtain $10 \mathrm{~mL}$ of the solution. The absorbance was measured by spectrophotometer UV-Vis (UV-1500; Analytik Jena, Poland) at $\lambda=725 \mathrm{~nm}$, after $90 \mathrm{~min}$ of incubation at obscurity. The results were expressed as mg gallic acid (GAL) equivalents. The standard curve $(\mathrm{y}=12,783 \mathrm{x}, \mathrm{R} 2=0,9988)$ was obtained on the basis of absorbance measurements of a gallic acid standard solution $(0.2 \mathrm{~g} / \mathrm{L})(21)$.

\section{Determination of total flavonoid content}

The total flavonoid content was determined using the Dowd method. The $5 \mathrm{~mL}$ of $2 \%$ aluminum trichloride $\left(\mathrm{AlCl}_{3}\right)$ in methanol was mixed with the same volume of the extract solution. Absorption readings at $\lambda=415 \mathrm{~nm}$ using spectrophotometer UV-VIS were taken after $10 \mathrm{~min}$ of incubation at obscurity. The flavonoid content was determined using a standard curve $\left(\mathrm{y}=5.4953 \mathrm{x}-0.0072, \mathrm{R}^{2}=0.9958\right)$ with quercetin (Qe) as the standard (22). 


\section{Statistical analysis}

The statistical analysis was conducted using the statistical program StatSoft, Inc. (2013) STATISTICA (data analysis software system), version 12, and Microsoft Office Excel (2003). The result of the test materials was the average value of three measurements. Analyzing the differences between variables within all study groups, for the normal distribution, an ANOVA test was used. In the absence of normality, the Kruskal-Wallis test was used. Analyzing the differences between the two groups, a Student's t-test or Mann-Whitney U test were employed. The strength of the correlations of flavonoids with polyphenols, flavonoids with DPPH and DPPH with polyphenols were measured using Spearman rank correlation, assuming the strength of correlation relationships: $\mathrm{rxy}=0$ none, $0<\mathrm{rxy}<0.1$ weak, $0.1<$ rxy $<0.3$ weak, $0.3<$ rxy $<0.5$ average, $0.5<$ rxy $<0.7$ high, $0.7<$ rxy $<0.9$ very high $0.9<$ rxy $<1$ nearly full correlation. In the data analyses carried out, $\alpha=0.05$ was assumed as the materiality level.

\section{RESULTS AND DISCUSSION}

Antioxidant potential of the tested products

The results of the antioxidant activity of polyphenol and flavonoid contents in goji products were presented in Table 1. The antioxidative potential expressed as the equivalent of Trolox in tested dried goji berries was varied $(p<0.05)$. The same results were observed also in juices and capsules (Table 1). Our results differed from those obtained by other authors (23).

Analyzing the antioxidant activity between the study groups, the highest values were observed in dried goji berries $(1610 \pm 258 \mu \mathrm{M}$ Trolox $/ 100 \mathrm{~g})$, then in juices $(293 \pm 123 \mu \mathrm{M}$ Trolox $/ 100 \mathrm{~mL})$, while the lowest value was observed in capsules $(218 \pm 51.8 \mu \mathrm{M}$ Trolox/100 g) (Table 1).

The statistically significant differences were observed between dried goji berries and juices as well as dried goji berries and capsules containing goji berries extract while no statistically significant differences were observed between juices and capsules (Table 1). It should be noted that the sample we studied was small. Different results were observed (19) in the study where a better antioxidant activity was visible in capsules than dried goji berries.

The lower antioxidant activity in juices and capsules compared to dried berries is probably a consequence of technological processes of the goji seeds, although studies have proved that the impact of technological processes on the antioxidant activity of a food is unclear (24-27). Pre-treatment i.e. peeling, cutting, or shredding reduces the antioxidative potential of plant material by 20 to $60 \%$ compared to the raw material due to the action of polyphenol oxidase (28). The processing performed using a high temperature causes further losses since most of the compound is an antioxidant, exhibits a high degree of liability due to degradation or

Table 1 . The content of polyphenols, flavonoids, and the ability to scavenge a DPPH radical in the analyzed goji berry products.

\begin{tabular}{|c|c|c|c|c|}
\hline $\begin{array}{l}\text { Group of } \\
\text { products }\end{array}$ & Product & $\begin{array}{c}\text { The ability to scavenge a DPPH } \\
\text { radical }(\mu \mathrm{M} \text { Trolox } / 100 \mathrm{~g} \text { or } \\
100 \mathrm{~mL})\end{array}$ & $\begin{array}{l}\text { Polyphenol content (mg } \\
\text { GAL/100 g or } 100 \mathrm{~mL})\end{array}$ & $\begin{array}{l}\text { Flavonoid content }(\mathrm{mg} \\
\text { Qe/100 g or } 100 \mathrm{~mL})\end{array}$ \\
\hline \multirow{4}{*}{ I } & No. 1 & $1516 \pm 68.0^{\mathrm{b}, \mathrm{c}}$ & $1094 \pm 33.3$ & $36.8 \pm 0.64^{\mathrm{b}, \mathrm{c}}$ \\
\hline & No. 2 & $1383 \pm 85.9^{\mathrm{a}, \mathrm{c}}$ & $1192 \pm 97.4$ & $49.1 \pm 3.84^{\mathrm{a}, \mathrm{c}}$ \\
\hline & No. 3 & $1929 \pm 106^{\mathrm{a}, \mathrm{b}}$ & $1252 \pm 39.1$ & $51.8 \pm 0.38^{\mathrm{a}, \mathrm{b}}$ \\
\hline & Anova test & 0.000664 & 0.059002 & 0.000435 \\
\hline \multirow{4}{*}{ II } & No. 4 & $339 \pm 21.1^{b, c}$ & $272 \pm 7.39^{\mathrm{b}, \mathrm{c}}$ & $18.3 \pm 0.91^{\mathrm{b}, \mathrm{c}}$ \\
\hline & No. 5 & $405 \pm 11.0^{\mathrm{a}, \mathrm{c}}$ & $221 \pm 7.82^{\mathrm{a}, \mathrm{c}}$ & $15.4 \pm 0.21^{\mathrm{a}, \mathrm{c}}$ \\
\hline & No. 6 & $135 \pm 5.45^{\mathrm{a}, \mathrm{b}}$ & $100 \pm 16.5^{\mathrm{a}, \mathrm{b}}$ & $9.00 \pm 0.18^{\mathrm{a}, \mathrm{b}}$ \\
\hline & Anova test & 0.000001 & 0.000004 & 0.000002 \\
\hline \multirow{4}{*}{ III } & No. 7 & $272 \pm 8.38^{\mathrm{b}, \mathrm{c}}$ & $280 \pm 41.6^{\mathrm{b}, \mathrm{c}}$ & $10.4 \pm 0.52^{\mathrm{b}, \mathrm{c}}$ \\
\hline & No. 8 & $227 \pm 8.69^{\mathrm{a}, \mathrm{c}}$ & $136 \pm 3.16^{\mathrm{a}}$ & $7.49 \pm 0.20^{\mathrm{a}}$ \\
\hline & No. 9 & $155 \pm 15.1^{\mathrm{a}, \mathrm{b}}$ & $151 \pm 5.13^{\mathrm{a}}$ & $6.83 \pm 0.06^{\mathrm{a}}$ \\
\hline & Anova test & 0.000042 & 0.000650 & 0.000023 \\
\hline
\end{tabular}

$\mathrm{X}$ - mean, SD - standard deviation, I - dried goji berries, II - juices goji berries, III - capsules containing goji berries extract, A - statistically significant difference with the first product in this group, B - statistically significant difference with the second product in this group, $\mathrm{C}$ - statistically significant difference with the third product in this group. 
enzymatic oxygen, and low resistance to environmental factors (27).

In the heating process of some plant products, an increase in antioxidant activity can be observed, associated with the emergence of new antioxidant compounds, e.g. ferulic and vanillic acid, proportional to the temperature used and the duration of the process (29). The beneficial effect of short-term treatment is associated with the removal of oxygen, denaturing enzymes from the group of oxidoreductases, and the transition of antioxidants into a more active form (aglycon) $(30,31)$, this may explain the highest antioxidant activity observed in dried goji berries compared to capsules and juices. In juices production technology, the reduction of the antioxidant capacity is associated with the separation of water-insoluble parts from cell juice, dilution of juices, clarification, and long-term storage of intermediates (27). Food ingredients with antioxidant properties may also react with each other, resulting in changes in antioxidant activity that are difficult to predict, and the processing processes used may further influence the type of these changes. This is mainly due to redox reactions between antioxidants and fat oxidation products, which may be the cause of the lowest antioxidative potential observed in the case of capsules. The Carlsen and Poiana studies also showed differences in unprocessed and processed plant samples $(32,33)$. Processed blueberry products, such as jam and syrup, performed about half the antioxidant activity of fresh berries.

\section{The content of polyphenols in the tested products}

Polyphenol and flavonoid belong to the group of secondary plant metabolites and constitute a diverse group of compounds with different antioxidant activity, depending on their structure, molecular weight, and concentration. In the case of flavonoids, it is important whether they are in the form of glycosides or aglycons, whereas in phenolic acids, the antioxidant activity is dependent on the presence of hydroxyl groups in the molecule in the -orto configuration (27). These substances have a high antioxidative potential, thus exhibiting cardioprotective properties, they also prevent cancer by preventing angiogenesis and excessive cell proliferation and also have anti-inflammatory properties $(34,35)$. Technological processes, depending on the type of product used and thermal processing, as the same as the antioxidant properties, may affect both the reduction and the increase in the content of polyphenol and flavonoid. In the case of analyzed dried goji berries, differences in polyphenol content were not statistically significant in relation to the origin. However, in Paradowska's study, varied content of polyphenols and flavonoids in dried Goji berries, depending on the manufacturer, was observed (12). In the tested juices, significant differences in the content of polyphenol associated with the source of origin $(\mathrm{p}<0.05)$ were observed. In the capsules statistically significant differences $(p<0.05)$ were observed between capsules 7 and 8 and between capsules 7 and 9 (Table 1).

The highest content of polyphenols in $100 \mathrm{~g}$ product per mg GAL was noted in dried berries (1179 $\pm 88.2 \mathrm{mg} \mathrm{GAL} / 100 \mathrm{~g})$, then in juices $(198 \pm 76.8 \mathrm{mg}$ GAL/100 mL). The lowest content was seen in capsules $(189 \pm 71.4 \mathrm{mg} \mathrm{GAL} / 100 \mathrm{~g})$ (Table 1).

Based on the obtained results it can be stated that the processing of goji berries may decrease polyphenol content. This is confirmed by Amakura Y. et al. (36) results in which the goji berries preserves (jelly and jam) were studied. They showed a reduction in the total phenol content during the processing of berries for jams that resulted in a lower content of antioxidants in processed berry products than in fresh fruits. In other studies on the plant, raw materials were also observed, often reducing the polyphenol content in processed products in relation to fruit $(37,38)$. This is due to the fact that polyphenols accumulate in the outer part of berries, and in particular in their peel (39), that is why in the case of obtaining some products (juice) most of the polyphenols remain in the pomace, and thus reduce their content. In addition, degradation may occur due to the action of endogenous enzymes, i.e. polyphenol oxidase and peroxidase (37). Due to the high lability, polyphenol compounds are also significantly degraded under the influence of increased temperature and storage time (38).

\section{The content of flavonoids in the tested products}

The significant differences in flavonoid content between the three study groups were observed $(\mathrm{p}<0.05)$. The highest content of flavonoids was observed in dried berries (45.9 $\pm 7.19 \mathrm{mg} \mathrm{Qe} / 100 \mathrm{~g})$, then for juices $(14.2 \pm 4.15 \mathrm{mg} \mathrm{Qe} / 100 \mathrm{~mL})$. The lowest content was observed in capsules $(8.24 \pm 1.67 \mathrm{mg}$ Qe/ $100 \mathrm{~g}$ ) (Table 1).

In the juice group, as well as in the dried goji fruits group, significant differences between flavonoid content $(\mathrm{p}<0.05)$ were observed. Regarding the capsules group, significant differences only between numbers 7 and 8 , and between numbers 7 and 9 (Table 1) were observed. This study showed that dried goji berries had the highest content of flavonoids, polyphenols, and antioxidant activity. 


\section{Relationship between the antioxidant activity with the content of polyphenols and flavonoids in tested products}

In three types of analyzed juices and capsules, a very strong or strong relationship between polyphenol content and scavenging ability of DPPH radical is the same as between flavonoid content and scavenging ability of DPPH radical. However, contrary to expectations, in dried goji berries, an average correlation between flavonoid and polyphenol content in relation to the scavenging ability of the DPPH radical was observed (Table 2). It may be related to the fact that the high antioxidative potential of juices and capsules is more connected with their composition, while dried goji berries may contain other antioxidants.

\section{The relationship between antioxidant activity, polyphenol and flavonoid content, and dose}

According to studies in the near future, Lycium Barbarum supplementation may provide a model for modern medicine with successful integration between traditional Asian and Western medicine, in the prevention and treatment of certain diseases (5). However, for it to be marketed, an established therapeutic dose standardized and quality-controlled for bioactive components is necessary (5). However, in the case of the dried fruit we purchased, the manufacturer did not provide dosage data or recommended intake. Such information only appeared for the capsules and two types of goji juice.

Therefore, it is not possible to conclude unequivocally which of the analyzed products would bring the greatest health benefits in a dose-dependent manner.
Table 2. The Spearman's rank correlation for dried goji berries, juices, and capsules.

\begin{tabular}{|c|c|}
\hline Parameter & $\begin{array}{c}\text { The ability to scavenge } \\
\text { a DPPH radical } \\
(\mu \mathrm{M} \text { Trolox } / 100 \mathrm{~g} \\
\text { or } 100 \mathrm{~mL})\end{array}$ \\
\hline \multicolumn{2}{|c|}{ Juices goji berries } \\
\hline $\begin{array}{c}\text { Polyphenol content } \\
\text { (mg GAL/100 mL juice) }\end{array}$ & $\begin{array}{l}\mathrm{R}=0.856 \\
\mathrm{p}=0.003\end{array}$ \\
\hline $\begin{array}{l}\text { Flavonoid content } \\
\text { (mg Qe/100 mL juice) }\end{array}$ & $\begin{array}{l}\mathrm{R}=0.848 \\
\mathrm{p}=0.004\end{array}$ \\
\hline \multicolumn{2}{|c|}{ Dried goji berries } \\
\hline $\begin{array}{c}\text { Polyphenol content } \\
\text { (mg GAL/100 g berries) }\end{array}$ & $\begin{array}{l}\mathrm{R}=0.423 \\
\mathrm{p}=0.257\end{array}$ \\
\hline $\begin{array}{l}\text { Flavonoid content } \\
\text { (mg Qe/100 g berries) }\end{array}$ & $\begin{array}{l}\mathrm{R}=0.433 \\
\mathrm{p}=0.245\end{array}$ \\
\hline \multicolumn{2}{|c|}{ Capsules containing goji berries extract } \\
\hline $\begin{array}{c}\text { Polyphenol content } \\
\text { (mg GAL/100 g extract) }\end{array}$ & $\begin{array}{l}R=0.683 \\
p=0.043\end{array}$ \\
\hline $\begin{array}{l}\text { Flavonoid content } \\
\text { (mg Qe/100 g extract) }\end{array}$ & $\begin{array}{l}R=0.86 \\
p=0.003\end{array}$ \\
\hline
\end{tabular}

\section{$\mathrm{R}$ - Spearman's rank}

Considering the samples for which the dosage was determined, the highest antioxidant activity/day among the capsules was found in sample No. 8 (114 $\mu \mathrm{g}$ Trolox/dose), followed by sample No. 7 (81.6 $\mu \mathrm{M}$ Trolox/dose) (Table 3). Sample No. 9 had antioxidant activity more than half that of sample No. 8 (46.5 $\mu \mathrm{M}$ Trolox/dose). In contrast, polyphenols were present in the highest amount in capsule No. 7 (84.0 mg GAL/dose), followed by No. $8(68.0 \mathrm{mg}$ GAL/dose) and No. 9 (45.3 mg GAL/dose). Only the flavonoid content of the capsules was comparable and

Table 3. DPPH, polyphenols, and flavonoids content depending on the daily dose (suggested on the package by the producer).

\begin{tabular}{|c|c|c|c|c|c|c|}
\hline \multirow{2}{*}{$\begin{array}{c}\text { Group of } \\
\text { products }\end{array}$} & Product & $\begin{array}{c}\text { Composition } \\
\text { Goji fruit extract } \\
\mathrm{mg} / \text { daily dose }\end{array}$ & $\begin{array}{c}\text { Recommended } \\
1 \text { dose/day }\end{array}$ & $\begin{array}{c}\text { The ability to } \\
\text { scavenge a DPPH } \\
\text { radical } \\
(\mu \mathrm{M} \text { Trolox/dose) }\end{array}$ & $\begin{array}{c}\text { Polyphenol } \\
\text { content (mg } \\
\text { GAL/dose) }\end{array}$ & $\begin{array}{c}\text { Flavonoid content } \\
\text { (mg Qe/dose) }\end{array}$ \\
\hline \multirow{4}{*}{ I } & No. 1 & data not available & data not available & data not available & data not available & data not available \\
\cline { 2 - 8 } & No. 2 & data not available & data not available & data not available & data not available & data not available \\
\cline { 2 - 8 } & No. 3 & data not available & data not available & data not available & data not available & data not available \\
\hline \multirow{3}{*}{ II } & No. 4 & data not available & data not available & data not available & data not available & data not available \\
\cline { 2 - 8 } & No. 5 & $150 \mathrm{mg}$ & $50 \mathrm{~mL} /$ day & 203 & 111 & 7.90 \\
\cline { 2 - 8 } & No. 6 & data not available & $50 \mathrm{~mL} /$ day & 77.5 & 50.0 & 4.50 \\
\hline \multirow{3}{*}{ III } & No. 7 & $300 \mathrm{mg}$ & 1 capsule/day & 81.6 & 84.0 & 3.12 \\
\cline { 2 - 8 } & No. 8 & $500 \mathrm{mg}$ & 1 capsule/day & 114 & 68.0 & 3.75 \\
\cline { 2 - 8 } & No. 9 & $300 \mathrm{mg}$ & 1 capsule/day & 46.5 & 45.3 & 2.05 \\
\hline
\end{tabular}

I - dried goji berries, II - juices goji berries, III - capsules containing goji berries extract. 
was $3.12 \mathrm{mg}$ Qe/dose, $3.75 \mathrm{mg}$ Qe/dose, and $2.05 \mathrm{mg}$ Qe/dose for samples 7, 8, and 9, respectively. For juices, the specific dose/day of juice No. 5 had a $3 \mathrm{rd}$ higher oxidative activity and twice as many polyphenols and flavonoids compared to sample No. 6 (203 $\mu \mathrm{g}$ Trolox/dose vs $77.5 \mu \mathrm{g}$ Trolox/dose, $111 \mathrm{mg}$ GAL/dose vs $50.0 \mathrm{mg}$ GAL/dose, 7.9 Qe/dose vs 4.5 Qe/dose).

Among the products for which dosage/day was given, large discrepancies were observed between the tested samples. Juice No. 5 also had the highest DPPH radical scavenging capacity and polyphenol and flavonoid content of all the products analyzed.

\section{CONCLUSIONS}

Dried goji berries had the highest content of polyphenol and flavonoid as well as the highest antioxidant activity among the analyzed products. Significantly lower content of these compounds was observed in the juices and the smallest in the capsules.

In all analyzed products, there was a high or very high-rank strength indicating the existence of a strong correlation between the scavenging capacity of DPPH radicals and the content of polyphenols and flavonoids. However, the high antioxidative potential of juices and capsules was more related to the presence in their composition of polyphenols and flavonoids than in dried goji fruits.

The obtained results concerning the beneficial influence on the health of the analyzed samples are characterized by a large discrepancy in terms of antioxidant properties, polyphenol, and flavonoid content depending on the product origin.

\section{CONFLICT OF INTEREST}

The authors declare no conflicts of interest.

\section{REFERENCES}

1. Ceccarini M.R., Vannini S., Cataldi S., Moretti M., Villarini M., et.al.: Biomed Res. Int. 2016, 9 pages (2016).

2. Potterat O.: Planta Med. 76, 7 (2010).

3. Olech M., Kasprzak K., Wójtowicz A, Oniszczuk T., Nowak R., et al.: Molecules 25, 4538 (2020).

4. Olatunji O.J., Chen H., Zhou Y.: Neurosci. Lett. 616, 111 (2016).

5. Neelam K., Dey S., Sim R., Lee J., Eong K.G.A.: Nutriens 13, 246 (2021).
6. Guo X.F., Li Z.H., Cai H., Li D.: Food Funct. 8, 1741 (2017).

7. Cai H., Yang X., Cai Q., Ren B., Qiu H., Yao Z.: Molecules 22, 12 pages (2017).

8. Kulczyński B., Groszczyk B., Cerba A., GramzaMichałowska A.: Nauka Przyr. Technol. 8, 19 (2014) (in Polish).

9. Tian X., Liang T., Liu Y., Ding G., Zhang F., Ma Z.: Biomolecules 9, 17 pages (2019).

10. Kulczyński B., Gramza-Michałowska A.: Post. Fitoter. 4, 247 (2014) (in Polish).

11. Ma Z.F., Zhang H., Teh S.S., Wang Ch.W., Zhang Y., et al.: Oxid. Med. Cell. Longev. 2019, 9 pages (2019).

12. Paradowska K., Czerniejewska M., Zielińska A., Sajkowska-Kozielewicz J.J.: Żywn. Nauka Technol. Jakość 4, 115 (2016) (in Polish).

13. Maleki S.J., Crespo J.F., Cabanillas B.: Food Chem. 299, 125124 (2019).

14. Zeng P.: Prog. Mol. Biol. Transl. Sci. 163, 423 (2019).

15. Chua Y.T., Ang X.L., Zhong X.M., Khoo K.S.: Singapore Med. J. 56, 11 (2015).

16. Mróz M., Ratajczak A.E., Korek E.: Alerg. Astma Immun. 25, 24 (2020) (in Polish).

17. Larramendi C.H., Garcia-Abujeta J.L., Vicario S., Garcia-Endiro A., Lopez-Matas M.A., et al.: J. Invest. Allergol. Clin. Immunol. 22, 5345 (2012).

18. Izzo A., Di Carlo G., Borrelli F., Ernst E.: Int. J. Cardiol. 98, 1 (2005).

19. Abreu K.D.B.R., Duarte N.C.B., Gris E.F., Orsi D.C., Silva I.C.R.D., et al.: Conference Paper. $10^{\text {th }}$ International Congress of Pharmaceutical Sciences (CIFARP) (2015).

20. Meléndez N.P., Nevárez-Moorillón V., Rodríguez-Herrera R., Espinoza J.C., Aguilar C.N.: Afr. J. Biochem. Res. 8, 14 (2014).

21. Wilczyńska A.: Bromat. Chem. Toksykol. 42, 870 (2009).

22. Medea A., Lamien C.E., Romito M., Millago J., Nacoulma O.G.: Food Chem. 91, 571 (2005).

23. Protti M., Gualandi I., Mandrioli R., Zappoli S., Tonelli D., Mercolini L.: J. Pharm. Biomed. Anal. 143, 252 (2017).

24. Nayak B., Liu R.H., Tang J.: Food Sci. Nutr. 55, 887 (2015).

25. Çubukçu H.C., Durak Kılıçaslan N.S., Durak I.: Sao Paulo Med. J. 137, 407 (2019).

26. Boari F., Cefola M., Gioia F., Pace B., Serio F., Cantore V.: Int. J. Food Sci. Nutr. 64, 870 (2013).

27. Gumul D., Korus J., Achremowicz B.: Żywn. Nauka Technol. Jakość 4, 41 (2005) (in Polish). 
28. Ali S., Khan A.S., Anjum M.A., Nawaz A., Naz S., et al.: Food Chem. 312, 126051 (2020).

29. Hayat K., Abbas S., Hussain S., Shahzad S.A., Tahir M.K.: Ind. Crops Prod. 140, 111610 (2019).

30. Grajek W.: Żywn. Nauka Technol. Jakość. 4, 26 (2003) (in Polish).

31. Różańska D., Regulska-Ilow B., Ilow R.: Probl. Hig. Epidemiol. 95, 215 (2014) (in Polish).

32. Carlsen M.H., Halvorsen B.L., Holte K., Bøhn S.K., Dragland S., et al.: Nutr. J. 9, 3 (2010).

33. Poiana M.A., Moigradean D., Dogaru D., Mateescu K., Raba D., Gergen I.: Rom. Biotechnol. Lett. 16, 6504 (2011).
34. Jasiński M., Mazurkiewicz E., Rodziewicz P., Figlerowicz M.: Biotechnologia 2, 81 (2009).

35. Islam T., Yu X., Badwal T.S., Xu B.: Chem. Cent. J. 11, 59 (2017).

36. Amakura Y., Umino Y., Tsuji S., Tonogai Y.: J. Agric. Food Chem. 48, 6292 (2000).

37. Kluszczyńsk D., Sowińska W.: Żywn. Nauka Technol. Jakość 4, 30 (2014) (in Polish).

38. Rembiałkowska E., Hallmann E., Adamczyk E., Lipowski J., Jasinska U., Owczarek L.: Żywn. Nauka Technol. Jakość 1, 121 (2006) (in Polish).

39. Garcia A., Pascual-Teresa S., Santos-Buelga C., Rivas-Gonzalo J.: Food Chem. 84, 13 (2004).

(C) 2021 by Polish Pharmaceutical Society. This is an open-access article under the CC BY NC license (http://creativecommons.org/licenses/BY/4.0/). 